\title{
AMBIENTES E VIDA NA TERRA - OS PRIMEIROS 4.0 Ga
}

\author{
Susana Ferreira ${ }^{1,2}$, M. Isabel Caetano Alves ${ }^{1,2,3}$ \& Pedro Pimenta Simões ${ }^{1,2,3}$
}

Resumo

Abstract

\begin{abstract}
O planeta Terra tem sofrido alterações ao longo do tempo geológico. Pouco tempo decorrido após a sua formação, há cerca de $4.6 \mathrm{Ga}$, era uma planeta homogéneo. Durante este longo intervalo de tempo, a Geosfera sofreu diversos processos de diferenciação geoquímica e geológica, responsáveis pelo desenvolvimento da actual estrutura interna da Terra. A formação da Atmosfera e da Hidrosfera ocorreu durante o Hadaico, aproximadamente entre $4.5 \mathrm{Ga}$ e $4.4 \mathrm{Ga}$.

A evolução e interacção dos sistemas terrestres, geosfera, atmosfera e hidrosfera, permitiu que fossem reunidas condições favoráveis ao aparecimento da Vida, há pelo menos $3.8 \mathrm{Ga}$.

As formas de Vida foram-se desenvolvendo em diversos ambiente, constituindo outro importante sistema terrestre, a Biosfera.

Este artigo tem como principal objectivo a compilação da informação mais relevante relacionada com os principais eventos e outros episódios significantes, que contribuíram para a origem da Vida e seu suporte, tendo como limite temporal o início do Fanerozóico.
\end{abstract}

Palavras - chave: Terra, evolução da geosfera, hidrosfera, atmosfera, biosfera, Hadaico, Proterozóico.

Environments and Life - the first 4.0 Ga in Earth. The planet Earth has been changing through the geologic time. The Earth was created about $4.6 \mathrm{Ga}$ ago as a homogeneous planet. During this long period of time, several processes occurred originating the geochemical and geological differentiation of the Geosphere and developing the present internal Earth structure. The formation of the Atmosphere and Hydrosphere occurred during the Hadean, approximately $4.5 \mathrm{Ga}$ to $4.4 \mathrm{Ga}$ ago.

The evolution and interaction of these important terrestrial systems (geosphere, atmosphere and hydrosphere) allowed, during Earth history, the development of vital conditions for the emergence of Life, at least $3.8 \mathrm{Ga}$ ago. The first organisms might have appeared from the most diverse environments constituting another important system, the Biosphere.

The main objective of this article is to compile the most relevant information related with major geological events and other significant episodes, which have contributed to the emergence of Life and its support throughout geological time until Early Paleozoic.

Key-words: Earth, development of geosphere, hydrosphere, atmosphere, biosphere, Hadean, Proterozoic.

\section{QUAL O INTERESSE PELOS AMBIENTES TERRESTRES TÃO ANTIGOS?}

A questão será certamente colocada pela maioria dos leitores relativamente ao título deste artigo, perante até alguma estranheza de o ler numa revista dedicada a um intervalo do tempo geológico muito curto e recente.

$\mathrm{Na}$ opinião dos autores este tema não tem fronteiras em aplicação.

O conhecimento dos ambientes mais antigos, cujas condições físico-químicas foram distintas da maioria das actuais, a sua evolução como consequência da evolução dos sistemas terrestres e relação destes com a Vida, beneficiará a visão humana sobre a evolução do planeta Terra e de alguns dos habitats actuais.
Neste artigo é apresentada uma compilação de conhecimentos, parte dum trabalho mais extenso (FERREIRA, 2007).

\section{ORIGEM E IDADE DA TERRA}

A sucessão de acontecimentos que levaram à origem da Terra e restantes corpos do Sistema Solar já reúne grande consenso. Diversas hipóteses foram propostas, mas a mais aceite actualmente é que o Sistema Solar tenha resultado da acreção e condensação de material interestelar, formado por gases e poeiras (a nébula solar), localizado num dos braços da galáxia Via Láctea.

Os elementos mais abundantes presentes na nébula solar, o hélio e o hidrogénio que se formaram nos primeiros momentos em que se deu

Núcleo de Ciências da Terra da Universidade do Minho.

Centro de Geologia da Universidade do Porto.

3 Universidade do Minho, Campus de Gualtar, 4710-057 Braga.

E-mails (segundo a ordem de autores): ferreira.susana@gmail.com; icaetano@dct.uminho.pt; pimenta@dct.uminho.pt 
a origem do Universo (Big Bang), ocuparam essencialmente a posição central dando origem ao Sol. Nas estrelas de dimensão superior à do Sol ocorreram e ainda ocorrem processos de nucleossíntese, a partir da fusão do hidrogénio e do hélio, originando novos elementos químicos, nos quais se incluem os elementos pesados. As abundâncias cósmicas actuais dependeram dos processos de produção estrelar de novos elementos. Por ordem decrescente de abundância relativa citase o hidrogénio, hélio, oxigénio, carbono, silício, ferro, entre os elementos mais abundantes. Os elementos mais pesados, como o ferro e o níquel, são formados durante os estádios finais das estrelas, pouco antes de ocorrer a fase de supernova, a explosão responsável pela dispersão dos elementos químicos pelo espaço interestelar (FAURE, 1998). O Sol foi o principal responsável pela primeira grande diferenciação geoquímica dos planetas do Sistema Solar, tendo contribuído para a vaporização dos materiais cósmicos que posteriormente condensaram de acordo com os respectivos pontos de fusão. Assim, os planetas que se formaram na região mais interior da nébula solar são constituídos por materiais rochosos e elementos que condensaram a elevada temperatura, enquanto que os planetas exteriores são compostos essencialmente por elementos voláteis, como o hidrogénio, hélio, amoníaco e metano, que condensaram a baixa temperatura. Na realidade, são as composições actuais dos planetas e de outros corpos do Sistema Solar, bem como a sua localização e comportamento, que levam à aceitação da Teoria da Nébula Solar (ZEILIK \& GREGORY, 1998; ALBARÈDE, 2003; BURNHAM et al., 2003).

Os métodos para determinação da idade da Terra e os materiais utilizados têm sido diferentes ao longo da História. A idade actualmente atribuída à Terra é de $4.6 \mathrm{Ga}$. Este valor foi obtido por métodos de datação absoluta, através de determinações radiométricas (DALRYMPLE, 2001). Enquanto a datação relativa permite a identificação da ordem sequencial de eventos em função da posição destes na coluna litológica, por datação absoluta são obtidos valores numéricos (FAURE, 1986; TORRES, 1994). Os materiais utilizados para a determinação da idade da Terra são as rochas mais antigas, os zircões e as galenas presentes nessas rochas, os meteoritos $\mathrm{e}$ as amostras lunares (KAMBER et al., 2001).

O desenvolvimento das técnicas de datação relativa e absoluta permitiu a elaboração da escala do tempo geológico, sendo este dividido em três éones: Arcaico (4.0 Ga - 2.5 Ga), Proterozóico $(2.5 \mathrm{Ga}$ - $542 \mathrm{Ma})$ e Fanerozóico (542 Ma actualidade). Alem destes é ainda considerado um quarto Éon, o Hadaico, cujo intervalo de tempo
$(4.6 \mathrm{Ga}-4.0 \mathrm{Ga})$ vai desde a formação da Terra até às rochas mais antigas encontradas neste planeta (GRADSTEIN et al., 2004).

A Terra pertence ao grupo dos planetas internos, sendo relativamente pequena quando comparada com os planetas externos. Contudo, apresenta um raio médio de $6371 \mathrm{~km}$ que lhe permitiu, em conjunto com outras características, reunir as condições necessárias à origem e desenvolvimento das primeiras formas de Vida. O tamanho, considerado ideal, permite a existência de uma camada gasosa em seu redor, a atmosfera. A existência de hidrosfera terrestre só é possível devido à distância a que o planeta Terra se encontra do Sol, responsável por valores de temperatura ideais para a maioria dos seres vivos conhecidos.

\section{Origem e EVOLUÇÃo dos Sistemas Atmosfera, Hidrosfera e Geosfera}

\subsection{Atmosfera}

O momento em que a atmosfera começou a desenvolver-se é difícil de determinar. Admite-se, contudo, que a sua composição não era igual à que conhecemos actualmente. Os dados indicam que era densa, quente, redutora e ácida, composta essencialmente por dióxido de carbono, monóxido de carbono, água, hélio, metano, amónia, sulfureto de hidrogénio, hidrogénio e azoto. Esta composição é determinada com base nos fenómenos que lhe deram origem (BURDIGE, 2006). A atmosfera deve ter sido originada a partir de gases remanescentes da nébula solar, gases resultantes do vulcanismo e gases resultantes do impacto de cometas e outros corpos celestes. Inicialmente a atmosfera era pobre em oxigénio e permaneceu assim durante algum tempo (KhARECHA et al., 2005). Foi no Arcaico que teve início o aumento no teor de oxigénio devido a dois processos: primeiro, pela dissociação fotoquímica da molécula de água e, mais tarde, por fotossíntese (FRIMMEL, 2005). A ocorrência de Formações de Ferro Bandado (Banded Iron Formation, abreviado BIF) em terrenos do Arcaico e Proterozóico, reflectem a deficiente concentração de oxigénio atmosférico no intervalo de tempo anterior a $1.8 \mathrm{Ga}$. O baixo teor de oxigénio permitiu que o ferro permanecesse em solução sob a forma de $\mathrm{Fe}^{2+}$ e fosse transportado para os oceanos, estando aí disponível para precipitar com o oxigénio livre ali produzido, constituindo as BIF, importantes formações ferríferas (OHMOTO, 2001; HOLLAND, 2003). Já no final do Proterozóico as formações do tipo BIF deixam de se formar mas ocorreu a génese de formações doutro tipo, as Red Beds. Estas e a ausência de uraninite e de pirite nos sedimentos 
evidenciam o aumento do teor de oxigénio livre na atmosfera. As Red Beds são rochas ferríferas de cor avermelhada, devido à presença de hematite $\left(\mathrm{Fe}_{2} \mathrm{O}_{3}\right)$, formada por oxidação do ferro em contacto com a atmosfera oxidante. Os minerais uraninite e pirite não são encontrados, pois não são estáveis em condições atmosféricas mesmo que levemente oxidantes (KNOPP et al., 2004; BARLEY et al., 2005). A partir daqui, a concentração em oxigénio foi aumentando na atmosfera. No Fanerozóico inicial a atmosfera apresentava já teores de oxigénio semelhantes aos que se verificam actualmente.

\subsection{Hidrosfera}

Relativamente à hidrosfera, em particular aos oceanos, é aceite que se formaram a partir de vapor de água resultante de processos vulcânicos. Mais recentemente tem sido admitida uma origem exógena para a água. De acordo com os defensores desta hipótese, os portadores da água foram os cometas. O momento exacto em que se formaram os oceanos também não é conhecido (STANLEY, 1999; HOLlAND, 2003). Contudo, existem informações directas e indirectas da presença de hidrosfera. Sabe-se que o oxigénio na natureza existe sob a forma de três isótopos: ${ }^{16} \mathrm{O},{ }^{17} \mathrm{O}$ e ${ }^{18} \mathrm{O}$. Quando os minerais interagem com água, por vezes adquirem maior ou menor quantidade de oxigénio ${ }^{18} \mathrm{O}$. Estudos realizados em zircões nas rochas de Jack Hills, no Oeste da Austrália, revelaram que os grãos daquele mineral apresentam uma assinatura isotópica caracterizada pelo enriquecimento em ${ }^{18} \mathrm{O}$. Esta informação geoquímica foi interpretada como sendo indicadora de zircões formados a partir de um magma, cuja composição teve contribuição de materiais crustais, alterados ou originados por processos de meteorização na presença de água no estado líquido, o que sugere a existência de hidrosfera desde há $4.3 \mathrm{Ga}$ - 4.4 Ga (KAMBER et al., 2001; MoJZSIS et al., 2001). As evidências geológicas directas indicam para este acontecimento um momento mais tardio na história da Terra. As rochas da Formação Gnaisses de Isua, datados de 3.7 Ga, apresentam basaltos em almofada, significando emissão de lava em meio aquático, ou seja a existência de hidrosfera no momento da sua génese. Quanto à temperatura nos oceanos, foi inicialmente mais elevada (HoLLAND \& KASTING, 1992). A salinidade começou por ser reduzida, tendo aumentado devido aos processos de meteorização das rochas continentais. A diminuição posterior da salinidade, para valores semelhantes aos actuais, foi provocada pela precipitação de rochas carbonatadas e evaporíticas. A composição da hidrosfera com o decorrer do tempo geológico foi marcada pelo aumento do $\mathrm{pH}$ e do teor em oxigénio, até estabilizarem nos valores actuais (BURDiGe, 2006).

\subsection{Geosfera}

A geosfera sofreu também modificação quer relativamente à morfologia quer à composição. Pouco tempo após a sua formação o planeta Terra era um corpo homogéneo. Devido aos intensos impactos meteoríticos, à compressão gravítica e à desintegração radioactiva, a temperatura do planeta aumentou. Como consequência, alguns materiais atingiram o ponto de fusão, distribuindo-se em profundidade, consoante a sua densidade (ANDREWs et al., 1996; ZEILIK \& GREGORY, 1998). Os elementos mais densos, como o ferro e o níquel, migraram para o centro constituindo o núcleo terrestre, iniciando-se assim a diferenciação interna da Terra, a qual originou a estrutura interior actual do planeta. Os elementos menos densos passaram a constituir o manto primitivo. Admite-se que parte do manto primitivo resultou da solidificação de um oceano magmático, com composição básica a ultrabásica. A diferenciação do manto primitivo originou o manto e a crusta terrestre, sendo esta pouco espessa e bastante instável (ANDREWs et al., 1996). Alguns investigadores consideram que a crusta oceânica se formou primeiro que a continental. Contudo, não há registos da primeira crusta. As rochas crustais mais antigas ocorrem nos territórios do Canadá (Slave Craton, extremo NW do Escudo do Canadá), têm cerca de $4.0 \mathrm{Ga}$, são os Gnaisses de Acasta, rochas de natureza siálica, portanto rochas da crusta continental (SHARMA \& PANDIT, 2003).

Vários modelos foram propostos para a formação da crusta continental: arcos vulcânicos (zonas de colisão e subducção) e zonas de rifte associadas a plumas mantélicas. Segundo os autores do primeiro modelo, a fusão parcial da crusta basáltica primitiva ao nível de zonas de subducção formou magmas com composição intermédia, que ascendendo na crusta originou arcos insulares de composição andesítica. A fusão parcial dos andesitos e a solidificação destes magmas permitiu o enriquecimento em sílica e alumínio, com formação de crusta siálica (MARTI \& ERNST, 2005). A observação de rochas félsicas na Islândia não se ajustam a este modelo, tendo sido admitido outro processo para a formação da crusta continental. Trata-se de processos semelhantes aos que ocorrem em zonas de rifte associadas a plumas mantélicas. Pequenos corpos félsicos situados na crusta oceânica sofrem fusão, devido ao magma máfico que se move ao longo das falhas, gerando vulcanismo de composição félsica (STANLEY, 1999). 
A formação da crusta continental criou pequenos cratões (os proto-continentes), provavelmente ainda no Hadaico. No final do Arcaico início do Proterozóico, deu-se um rápido crescimento crustal associado à colisão entre cratões. As placas tectónicas, em movimento de convergência, colidiram gerando zonas de subdução. Nestas situações geodinâmicas houve formação da crusta siálica e também a sua evolução composicional. Nestas zonas a crusta ultrabásica a básica, mais densa, foi sendo destruída enquanto a crusta siálica, menos densa, foi sendo preservada, formando inúmeros cratões siálicos de pequena dimensão durante o Arcaico (SHARMA \& PANDIT, 2003). Os processos crustais, com geração de crusta oceânica e continental, envolveram essencialmente a produção de rochas da Formação Greenstone Belts (GSB) e complexos granítico-gnaissícos, menos frequentes no Proterozóico (VAN KRANENDONK, 2006).

O estilo tectónico no Proterozóico passou a ser semelhante ao actual. São encontradas rochas do tipo GSB, BIF, associações de arenitos, carbonatos e argilitos, depósitos glaciários e no final do Proterozóico a Formação de Red Beds. Durante este Éon, que se caracteriza pelo rápido crescimento crustal, formaram-se os grandes continentes Laurentia e Gondwana. Nas zonas de colisão ergueram-se cordilheiras montanhosas, permitindo a adição de novos materiais aos continentes. Entre 1.3 $\mathrm{Ga}$ e $1.0 \mathrm{Ga}$ as massas continentais formavam um supercontinente, Rodínia, o qual se fracturou há cerca de $700 \mathrm{Ma}$ (WICANDER \& MONROE, 2000).

Os movimentos tectónicos no início do Fanerozóico inverteram o sentido, para divergência, provocaram a fracturação do supercontinente Rodínia e a separação das massas continentais. No fim da Era Paleozóica, do Éon Fanerozóico, o sentido do movimento dos continentes resultantes foi novamente de convergência. A reunião dos continentes foi completa, formando um único supercontinente a Pangeia, rodeado por um vasto oceano, o Pantalassa. Ao contrário do ocorrido nos éones anteriores, as rochas da Era Paleozóica, do Éon Fanerozóico, não se encontram tão metamorfizadas, deformadas e erodidas. Apresentam um elevado conteúdo fossilífero, numerosas evidências do padrão geodinâmico continental e de outros processos geológicos neste intervalo de tempo: formação de cadeias montanhosas, erosão da superfície continental, arrefecimento climático e formação de depósitos glaciários, entre outras (SKINNER \& PORTER, 2003).

Enquanto suporte para a Vida, a evolução da geosfera condicionou a evolução da biosfera. $\mathrm{Na}$ realidade, todas as esferas terrestres interagem mutuamente pois são sistemas abertos.

\section{REQUISITOS PARA ORIGEM DA VIDA}

A Vida surgiu envolta deste turbilhão evolutivo! Como se originou? Em que ambientes? Que relação com a geosfera? Não existe uma, mas sim um conjunto de respostas para estas questões. As respostas por vezes são diferentes consoante o investigador a que forem colocadas.

\subsection{Elementos e compostos químicos vitais}

São necessários dois requisitos para a Vida tal como a conhecemos hoje: a presença de água no estado líquido e de polímeros orgânicos (SCHOPF, 1992, 2001; BADA, 2004; DOBRETSOV et al., 2006). As propriedades únicas da água são essenciais para que determinadas reacções químicas ocorram. Por outro lado, os polímeros (macromoléculas) são usados nas funções biológicas como a replicação e metabolismo (SCHOPF, 2001; BADA, 2004). Para além dos lípidos e dos glícidos, os dois tipos essenciais de macromoléculas encontradas nos seres vivos são as proteínas e os ácidos nucleicos, ADN e RNA.

Praticamente todos os investigadores neste tema estão de acordo que foi necessária quer uma fonte de elementos químicos apropriados, a partir dos quais as moléculas orgânicas foram sintetizadas, quer uma fonte de energia que promovesse essas mesmas sínteses.

Os principais elementos químicos que constituem as moléculas orgânicas são o carbono, o hidrogénio, o azoto e o oxigénio, elementos que estavam presentes na atmosfera sob a forma de dióxido de carbono $\left(\mathrm{CO}_{2}\right)$, vapor de água $\left(\mathrm{H}_{2} \mathrm{O}\right)$, azoto $\left(\mathrm{N}_{2}\right)$, metano $\left(\mathrm{CH}_{4}\right)$ e amónia $\left(\mathrm{NH}_{3}\right)$. Admitese que estes elementos necessários à Vida se combinaram dando origem a monómeros, como por exemplo os aminoácidos e as bases azotadas. A fonte de energia para estas reacções foi, muito provavelmente, a radiação ultravioleta e as descargas eléctricas (ROLLINSON, 2001; DOBRETSOV et al., 2006).

\subsection{Blocos constituintes da Vida}

Qual foi a origem dos blocos constituintes da Vida? Foram o resultado de uma evolução prébiológia que decorreu na Terra ou foram trazidos para o nosso planeta?

Estas questões, apesar de postularem duas situações muito diferentes, recebem ambas respostas afirmativas. De facto, actualmente existem dois modelos principais: um admite que os blocos constituintes da Vida foram gerados através 
da síntese abiótica na Terra, modelo endógeno; outro que defende a proveniência através de fontes extraterrestres, modelo exógeno (PANOV, 2005).

Os monómeros são considerados os blocos constituintes da Vida, pois é a partir destes que se formam moléculas orgânicas mais complexas, constituintes das células e que estão na base da Vida. Da associação de blocos constituintes, através de ligações químicas, resultam polímeros importantíssimos.

As experiências laboratoriais, como a de Stanley Miller, mostram que os blocos constituintes da Vida podem ser sintetizados em laboratório (OPARIN, 1929/1938; SCHOPF et al., 2002). Miller sintetizou experimentalmente diversos aminoácidos, aldeídos, cetonas e cianeto de hidrogénio a partir da mistura de gases (metano, amónia e vapor de água), sujeita a descargas eléctricas e posterior arrefecimento (Fig. 1).

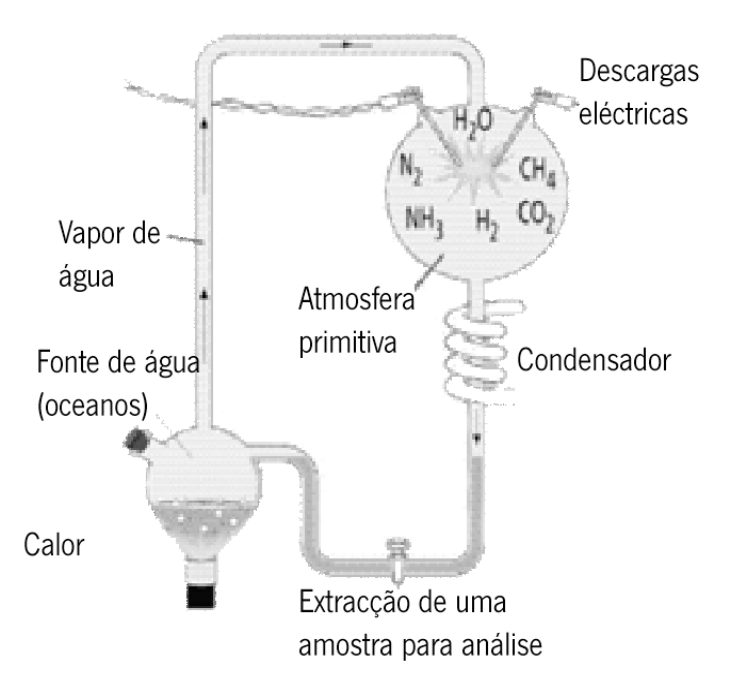

Fig. 1 - Dispositivo experimental usado por Stanley Miller (adaptado de FARABEE, 2001).

Fig. 1 - Representation of Miller's experimental apparatus (adapted from FARABEE, 2001).

Devido ao impacto causado em 1950 pela experiência de Miller, a grande maioria dos autores admite a existência de uma evolução pré-biológica na Terra, ou seja, uma evolução antes do surgimento da Vida (RUSSEL \& HALL, 1997; SCHOPF et al., 2002; WALDE, 2006).

Outros investigadores admitem que a Vida possa ter vindo do espaço. Esta ideia não é nova, já em 1871 Lord Kelvin (KELVIN, 1871) afirmou que os germes da Vida podem ter sido trazidos para a Terra por algum meteorito, mas só recentemente conquistou mais adeptos. A composição de meteoritos, analisados nas últimas décadas, tem sido estudada e alguns investigadores sugerem a possibilidade de origem extraterrestre da matéria orgânica, a partir da qual a Vida se desenvolveu na
Terra. Outros admitem que a própria Vida possa ter tido origem extraterrestre (COWEN, 2004).

\subsection{Passos para a Vida: a polimerização}

O verdadeiro desafio não é criar aminoácidos, mas sim proteínas. Além de explicar a origem dos blocos constituintes da Vida, é preciso dar resposta ao modo como estes se organizaram para formar células capazes de crescimento, replicação e transmissão da informação genética.

Explicar o modo como ocorreu a polimerização é mais complicado. A proteína resulta da junção de aminoácidos numa determinada ordem, da mesma maneira que se juntam letras do alfabeto para criar palavras (ENGEL \& MACKO, 1993).

Entre os vários investigadores que trabalharam em condições de simulação da atmosfera redutora destacam-se os trabalhos de Sidney Fox. Utilizando uma mistura semelhante à de Miller e aquecendo-a, este bioquímico sintetizou pequenas moléculas designadas de proteinóides, as quais consistem em ligações de mais de 200 aminoácidos (WICANDER \& Monroe, 2000). Contudo, para serem consideradas formas de Vida, têm que se individualizar do meio envolvente e adquirir auto-suficiência, tal como as células actuais (COWEN, 2004). Por esta razão, a aquisição de uma membrana envolvente e o desenvolvimento de catalizadores são considerados como sucessos evolutivos posteriores (WALDE, 2006).

\subsection{Individualização orgânica e replicação}

Outras experiências realizadas por Sidney Foz conduziram à síntese de proteínas em laboratório, os proteinóides, os quais formavam agregados espontaneamente mais ou menos organizados, as microesferas (BOWLER, 2003).

A formação, em laboratório, das microesferas constituiu uma etapa científica importante, pois representa o efeito de aproximação das moléculas entre si, a respectiva individualização relativamente ao meio circundante, como consequência da formação de "membranas" a partir de materiais orgânicos, essencialmente proteínas e lípidos (DEAMER, 2000).

As microesferas de Fox eram capazes de aumentar de volume e dividir-se espontaneamente, fenómeno que pode ser associado à capacidade de replicação, exclusiva dos seres vivos. Esta autoorganização espontânea levou ao surgimento da hipótese "lipid world" (mundo dos lípidos), cujos autores admitem que não foi só uma molécula anfipática (fosfolípido) que teve um importante 
papel na origem da Vida mas sim todos os lípidos em geral (WALDE, 2006).

No entanto, actualmente sabe-se que para a replicação é necessária a intervenção dos ácidos nucleicos, ADN e RNA. Todavia, estas moléculas não são capazes de se replicar na ausência de enzimas (proteínas), da mesma forma que as enzimas não podem ser sintetizadas na ausência de ácidos nucleicos (ORGEL, 2006).

Muito recentemente foi observado experimentalmente que pequenas moléculas de RNA são capazes de se auto-replicarem sem a intervenção de enzimas. Com base nesta descoberta, parece evidente que o primeiro sistema capaz de auto-replicação pode ter sido a molécula de RNA; neste caso a hipótese "RNA world" (mundo do RNA). Segundo os seus autores, estas moléculas foram intermediárias entre os compostos químicos inorgânicos e os organismos (ORGEL, 2006; WALDE, 2006). Foi a primeira molécula capaz de multiplicação, hereditariedade e variabilidade, fenómenos que marcam o grande passo para as primeiras formas de Vida e posterior evolução (BADA, 2004). Contudo, é pouco provável que a molécula de RNA tenha surgido espontaneamente porque se trata de uma molécula muito instável nas condições da Terra primitiva. Por este motivo muitos autores admitem que existiu uma molécula capaz de reter informação, não necessariamente o RNA ou ADN, mas um ácido nucleico peptídico (PNA), mais estável (BADA, 2004). Qualquer que tenha sido a molécula percursora da Vida, actualmente a ideia de que a Vida é um produto da evolução é aceite pela maioria dos investigadores (CAIRNS-SMITH, 1990).

Parece ser consensual que o "mundo do ADN/Proteínas" foi posterior ao do RNA. A instabilidade do RNA pode ter sido uma razão para esta transição. O ADN, mais estável e com capacidade de armazenar a informação, começou a ser transmitido às gerações seguintes, tendo o RNA assumido o papel de intermediário para a biossíntese de proteínas a partir da informação contida no ADN (BADA, 2004).

\section{QUAIS OS AMBIENTES PROPÍCIOS À VIDA?}

A determinação do ambiente favorável à origem da Vida na Terra constitui um tema em que as opiniões são diversas, existindo várias propostas sustentadas em observações actuais. A Vida na Terra está presente em ambientes com características muito variadas, alguns aparentemente inóspitos.

No seio da diversidade de ambientes terrestres têm sido sugeridos muitos locais para o surgimento da Vida: sopa primitiva presente no fundo dos oceanos (OPARIN, 1938), superfícies de minerais de argila (CAIRNS-SMITH, 1985), superfície de grãos de pirite (TRIBUTSCH et al., 2003), sistemas hidrotermais (CORLISS et al., 1981; Corliss, 1989; CoCKell, 2004), solos, atmosfera, espaço, lagos, lagunas e ilhas vulcânicas em locais da Terra com temperatura baixa (COWEN, 2004).

$\mathrm{O}$ espaço e a atmosfera eram demasiado secos enquanto que nos solos é possível que não existisse quantidade suficiente de matéria orgânica, tal como existia nos reservatórios de água (COWEN, 2004; DOBRETSOV et al., 2006). A presença de determinados compostos químicos (bases azotadas e açucares) em meteoritos contraria a ideia de um espaço sideral pobre em matéria orgânica.

É quase totalmente consensual que o tipo de ambiente onde teve origem a Vida foi o aquático. No entanto, alguns investigadores não rejeitam a possibilidade da Vida ter surgido em ambientes terrestres ao mesmo tempo que surgiu nos aquáticos. Contudo, como a crusta continental demorou algum tempo a estabilizar admitem que a Vida não resistiu. Por outro lado, a Terra passou por vários períodos de glaciações em que, durante uma ou duas glaciações, o planeta esteve totalmente coberto de gelo (KAUFMAN et al., 1997).

Segundo Sankaran (2001) a Vida sob a forma de seres muito simples teve origem nos oceanos durante o Arcaico inicial, há mais de $3.8 \mathrm{Ga}$, pois os fósseis anteriores ao Ordovícico-Silúrico pertencem apenas a seres marinhos. A Vida em ambientes terrestres não aquáticos pode ter sido posterior à origem da Vida aquática (SANKARAN, 2001).

As condições do meio marinho não são quimicamente favoráveis às moléculas orgânicas, pois estas são extremamente vulneráveis ao sódio e cloro presentes na água, e, assim, parece ser pouco provável que a Vida se tenha iniciado em meio marinho (COWEN, 2004). É mais provável que a Vida se tenha desenvolvido em lagos ou lagunas, essencialmente em condições análogas às de climas tropicais, onde a temperatura é elevada, facilitando as reacções químicas. Porém, estes tipos de ambientes tão pouco são irrefutáveis. As bases constituintes do RNA são pouco estáveis a temperatura elevada, o que torna as águas tropicais demasiado quentes $\left( \pm 25^{\circ} \mathrm{C}\right)$ para a origem da Vida (COWEN, 2004). O mesmo acontece com as enzimas que desnaturam rapidamente a temperatura $\geq 40{ }^{\circ} \mathrm{C}$. Estes condicionalismos limitaram, desde logo, o ambiente onde as biomoléculas percursoras de Vida se formaram, de modo a que sobrevivessem num intervalo de tempo suficiente para posterior evolução. Por este motivo, Cowen (2004) considera que muito provavelmente o melhor ambiente para a origem da Vida possa ter sido as ilhas vulcânicas 
existentes em locais da Terra com temperatura baixa, onde eram reunidas condições muito diversificadas: actividade vulcânica, tempestades, relâmpagos e neve. Se de facto a Vida teve origem neste tipo de paleoambientes ela começou em meio terrestre e aquático.

A atmosfera inicial era essencialmente composta por $\mathrm{CO}_{2}, \mathrm{~N}_{2}, \mathrm{H}_{2}, \mathrm{NH}_{3}, \mathrm{CH}_{4}$ e continha menos de $1 \%$ do teor de oxigénio presente actualmente. A pequena percentagem de oxigénio produzido pode ter sido usada na oxidação de minerais de ferro. $\mathrm{O}$ efeito mais importante resultante da ausência de uma elevada quantidade de oxigénio foi a incapacidade de se formar a camada de ozono, que desempenha um papel na protecção da Vida contra as radiações UV letais em meios não aquáticos (SANKARAN, 2001; COCKELl, 2004). Assim, só num ambiente a Vida poderia estar protegida das radiações UV: no fundo dos oceanos, mais concretamente nas cristas médio-oceânicas. Nestas, o calor libertado nas zonas de rifte é responsável pelo aquecimento da água e consequente formação de fontes hidrotermais, que puderam ter contribuído como fontes de hidrogénio $\left(\mathrm{H}_{2}\right)$, sulfureto de hidrogénio $\left(\mathrm{H}_{2} \mathrm{~S}\right)$, metano $\left(\mathrm{CH}_{4}\right)$ e, possivelmente, cianeto de hidrogénio $(\mathrm{HCN})$, percursor de moléculas orgânicas (BADA, 2004). Os sistemas hidrotermais podem ter sido locais propícios ao estabelecimento de ligações químicas favorecidas pela temperatura e pressão elevadas frequentes nestes domínios (CAIRNS-SMITH, 1990; HAZEN et al., 2002; RUSHDI \& SIMONEIT, 2006). Efectivamente, as reacções de condensação de moléculas lipídicas anfipáticas ocorrem facilmente sob estas condições assim como outras sínteses biológicas (RUSHDI \& SIMONEIT, 2006). As descobertas recentes de Vida abundante junto a chaminés hidrotermais submarinas, constitui um forte argumento para os defensores destas ideias (HAZEN et al., 2002). Naqueles ambientes foram encontrados ecossistemas ligados à química do enxofre, de grande riqueza biológica, contendo na base da cadeia alimentar bactérias que reduzem o enxofre e estão entre as entidades mais primitivas conhecidas. Estes ecossistemas são possivelmente testemunhos relíquia das primeiras comunidades biológicas que povoaram o nosso planeta. Contudo, pensa-se que no Arcaico a produção de nova crusta oceânica foi de cerca $100 \mathrm{~km}^{3}$ por ano. Na presença de todo este dinamismo será que a Vida teve a capacidade de se instalar nestas zonas do planeta?

Diversos estudos suportam ainda a ideia de que a primeira forma de vida foi hipertermófila, muito provavelmente um sobrevivente do intenso impacto que aqueceu o oceano. Actualmente são conhecidas formas de Vida capazes de se desenvolver em locais com temperatura muito elevada, como é o caso das bactérias de Octopus Spring, no parque americano de Yellowstone, e das cianobactérias encontradas num géiser, no Nevada. Porém, esta hipótese de um ancestral comum hipertermófilo é muito recente e não recolheu muitos argumentos a favor. Uma alternativa interessante e ainda pouco conhecida é a de que o ancestral comum possa ter sido uma bactéria planctónica não hipertermófila. Esta hipótese surge na sequência de estudos realizados em RNA ribossómico (WOESE, 1998).

Recentemente foi sugerido um novo ambiente que pode ter constituído um abrigo de protecção à Vida, não só dos impactos iniciais como também das radiações UV: as rochas (COCKELL, 2004). Apesar de ser difícil testar esta ideia experimentalmente, sabe-se que a meteorização física e química das rochas, à semelhança de outros processos geológicos, era bastante intensa na Terra primitiva. As cavidades das rochas resultantes da meteorização podem ter fornecido microambientes propícios ao desenvolvimento da Vida (COCKELL, 2004). Outro aspecto que apoia esta ideia é a presença de microorganismos heterotróficos em gnaisses no Árctico, o que sugere que possivelmente as biomoléculas podem ter sofrido a evolução pré-biológica nas rochas (COCKELL, 2004).

Os depósitos com grãos de alguns minerais tiveram também particular importância. Algumas reacções químicas foram possíveis por terem tido lugar em superfícies minerais (pirite e minerais de argila), que catalizaram polimerizações na presença de água. Este tipo de catálise já foi demonstrada em laboratório e tudo leva a pensar que ocorreu na Terra primitiva.

A pirite, frequente nos ambientes sedimentares primitivos, contém cargas positivas que podem induzir, por atracção eléctrica, a reunião de moléculas orgânicas carregadas negativamente, aproximando-as o suficiente para se unirem. Os minerais de argila possuem uma estrutura cristalina em folhas, cujo padrão se repete e pode reproduzir eventuais defeitos na malha cristalina, de modo algo similar a uma mutação numa cadeia de ADN. Alguns investigadores (CORLISS et al., 1981; CORLISS, 1989; CAIRNS-SMITH, 1990) estudam a possibilidade dos minerais de argila e outras estruturas poderem ter desempenhado um papel importante como matrizes, controlando os primeiras etapas da síntese pré-biológica.

As evidências e interpretações não apontam de modo seguro que o surgimento da Vida tenha sido nos oceanos. Além do entrave da salinidade, já referido, actualmente sabe-se da existência de organismos resistentes a radiações UV. Desta forma, a ausência de camada de ozono não é argumento suficiente para que não possamos admitir que a Vida se tenha originado fora dos 
oceanos. É sabido que o processo de fossilização ocorre mais facilmente em ambientes aquáticos, locais onde é mais eficaz o isolamento dos cadáveres. Mas o facto da maioria dos fósseis serem encontrados em estratos marinhos não prova que a origem da Vida tenha sido no meio oceânico.
Apesar de se tratar de uma questão em aberto, as evidências de Vida em ambiente terrestre continental surgiram apenas entre $3.0 \mathrm{Ga}$ e $2.5 \mathrm{Ga}$ (Fig. 2).

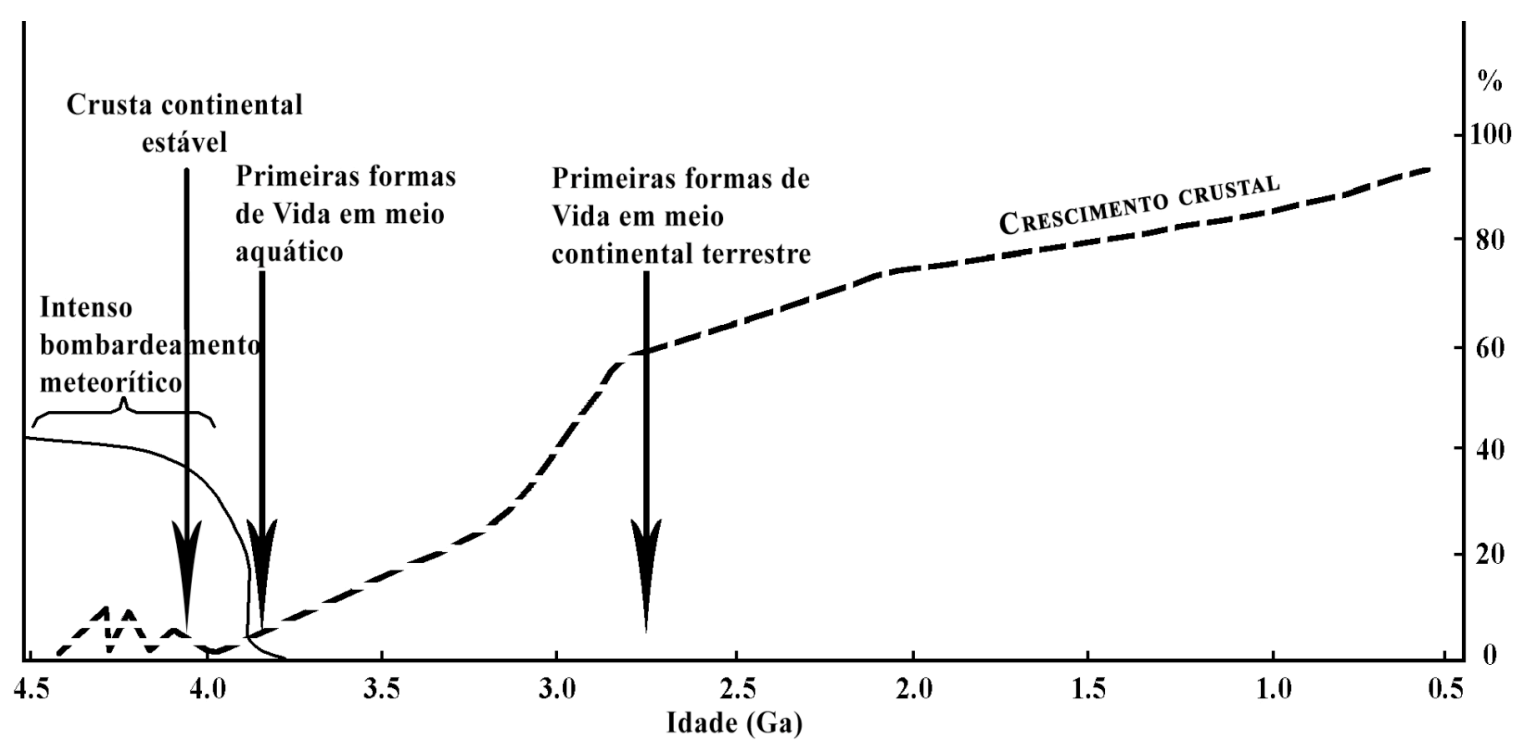

Fig. 2 - História geológica dos principais eventos com referência às etapas da Vida na Terra. (adaptado de SANKARAN, 2001).

Fig. 2 - History of geological events with reference to Life on Earth (adapted from SANKARAN, 2001)

\section{GEOFONTES DISPONÍVEIS}

Para a origem da Vida foi necessária a disponibilidade de compostos químicos e energia. É na quebra das ligações estabelecidas entre os elementos químicos que os seres vivos retiram a energia de que necessitam (COWEN, 2004; MULLER \& SCHUlZE-MARUCH, 2006).

Durante a fase final da acreção do planeta e especialmente após a formação da Lua há $4.51 \mathrm{Ga}$, a superfície da Terra era um oceano de magma. A água existente à superfície estava presente na atmosfera sob a forma de vapor. A elevada temperatura que possivelmente existiu, conduziu à destruição de compostos orgânicos e inorgânicos. Assim, é possível admitir que no início da sua história a Terra estivesse praticamente desprovida de compostos químicos (RUSSEL \& HALL, 1997; BADA, 2004).

Apesar do registo litológico ser escasso, a composição isotópica de zircões detríticos com 4.4 $\mathrm{Ga}-4.0 \mathrm{Ga}$ indica que a temperatura na superfície da Terra desceu até ao ponto de permitir a presença de água no estado líquido (AMELIN, 2005). A acumulação de água, no estado líquido, fez baixar a temperatura nos ambientes sedimentares o suficiente para permitir a permanência de compostos orgânicos derivados de variadas fontes (BADA, 2004). Por esta razão é frequente aceitar-se que no intervalo entre $4.4 \mathrm{Ga}$ e $4.0 \mathrm{Ga}$ possam ter ocorrido algumas etapas importantes na construção da Vida na Terra (BADA, 2004).

\subsection{Fontes de compostos químicos}

Tendo em conta que actualmente os oceanos são alimentados pelos rios, glaciares e vento que transportam materiais resultantes da meteorização continental, supõe-se que o mesmo ocorreu no passado.

Os processos de meteorização das rochas levam à alteração e desagregação das rochas préexistentes. A meteorização física ou mecânica consiste na fragmentação dos materiais existentes causada pela variação de temperatura, congelamento da água, precipitação de sais nas fissuras das rochas, actividade dos seres vivos, entre outros. A meteorização química consiste na modificação mineralógica da rocha, por acção da 
água líquida misturada com gases atmosféricos, conduzindo à alteração dos minerais pré-existentes e formação de novos minerais, minerais de neoformação. Os materiais resultantes (sedimentos e soluções ricas em iões) são transportados, acumulando-se em lagos e alguns atingindo os oceanos. É possível que os oceanos primitivos fossem ricos em compostos químicos provenientes destas fontes continentais.

Os sistemas hidrotermais presentes na Terra são constituídos essencialmente por rochas ígneas básicas ricas em olivina. Nestes sistemas, a reacção mais importante de hidrólise de silicatos é a alteração do mineral olivina em serpentina e magnetite (serpentinização). Como esta reacção liberta voláteis $\left(\mathrm{H}_{2}, \mathrm{CH}_{4}\right)$ e produz soluções básicas, os locais de activa serpentinização constituíram ambientes favoráveis para os seres vivos na Terra primitiva (ISLAS et al., 2003; KELLEY et al., 2005). Diversas experiências têm sido realizadas, nas quais é simulada a serpentinização. Os resultados mostram que, durante a hidrólise de olivina, os seres desenvolvem-se rapidamente. Este tipo de paleoambientes, sistemas hidrotermais, abundantes na Terra primitiva, foram possivelmente ambientes favoráveis para o desenvolvimento de microorganismos. De facto, esta ideia já não é nova. Em 1984, Neal \& Stanger sugeriram que, no tempo pré-biótico, o hidrogénio dos sistemas hidrotermais possa ter contribuído significativamente para a síntese das primeiras moléculas orgânicas (Rollinson, 2001). Já em 1953, Pringle admitia que era precisamente nos oceanos que estavam reunidas as condições para a origem da Vida pois constituíam um grande reservatório de compostos químicos.

\subsection{Fontes de energia}

A Vida na Terra utiliza luz e determinadas substâncias químicas como fonte de energia (Muller \& SChUlze-Maruch, 2006). É possível que na Terra primitiva não fosse muito diferente. As primeiras células desenvolveram-se possivelmente em ambiente aquático onde abundavam grande quantidade de compostos orgânicos. Obtinham energia a partir das moléculas de ATP (adenosina trifosfato), aminoácidos e outros compostos químicos que pudessem absorver do meio (COWEN, 2004).

O aumento do número das células devido à reprodução deve ter criado uma crise energética por défice de compostos orgânicos disponíveis. As células passaram a competir pelo alimento, sendo necessária outra forma de obtenção de energia (SNOOKS, 2005). Enquanto os organismos heterotróficos obtêm a energia metabólica através da quebra das ligações químicas de moléculas que absorvem, o mesmo não acontece com os autotróficos que produzem as suas próprias moléculas com a intervenção da energia do meio, geralmente a luminosa (COWEN, 2004; DOBRETSOV et al., 2006).

\section{AMbientes e REgisto FósSIL do ARCAICo}

As evidências de Vida na Terra durante o Arcaico são encontradas apenas em algumas rochas, mas este facto não significa que não tenha sido abundante. É importante distinguir claramente entre presença de Vida e a sua preservação. A ausência de fósseis não deve ser interpretada como ausência de Vida. No Éon Arcaico a dificuldade é acrescida pela raridade de rochas e, como tal, do registo fóssil.

O conhecimento actual das formas de Vida existentes na Terra durante o Arcaico é baseado em evidências directas e indirectas. As primeiras, referem-se ao conteúdo fossilífero dos estratos sedimentares, enquanto que, as segundas resultam de determinações isotópicas de compostos, cuja origem possa ter sido biológica. O registo fóssil fornece informações sobre o tipo de seres vivos que povoaram a Terra primitiva e, indirectamente, sobre as características dos ambientes.

\subsection{Evidências directas de Vida}

O intervalo de tempo geológico anterior ao Câmbrico, designado informalmente por PréCâmbrico, foi no passado histórico descrito como o intervalo da história da Terra sem existência de Vida, tendo sido designado por Azóico (ausência de Vida). No início de 1900, Charles Walcott (1850 1927) encontrou, nos EUA, estruturas actualmente chamadas de estromatólitos. Estas estruturas sedimentares (Fig. 3) representam recifes construídos por algas azuis (cianobactérias), seres unicelulares fotossintéticos (SCHOPF, 1992, 2001; FENCHEL, 2003). Os estromatólitos formam-se em ambientes onde o carbonato de cálcio $\left(\mathrm{CaCO}_{3}\right)$ é abundante sendo por isso encontrados essencialmente em rochas sedimentares carbonatadas (FENCHEL, 2003).

$\mathrm{Na}$ actualidade os recifes de cianobactérias (estromatólitos) são raros devido ao fraco crescimento e aos predadores existentes. No PréCâmbrico eram bastante frequentes (SCHOFF, 1992). Os mais antigos foram encontrados na Austrália, na Formação Apex Chert datada em $3.5 \mathrm{Ga}$, e na África do Sul, em rochas de idade aproximadamente $3.3 \mathrm{Ga}$ a $3.5 \mathrm{Ga}$ (SCHOPF, 2001; GREGÓRIO \& SHARP, 2003). 


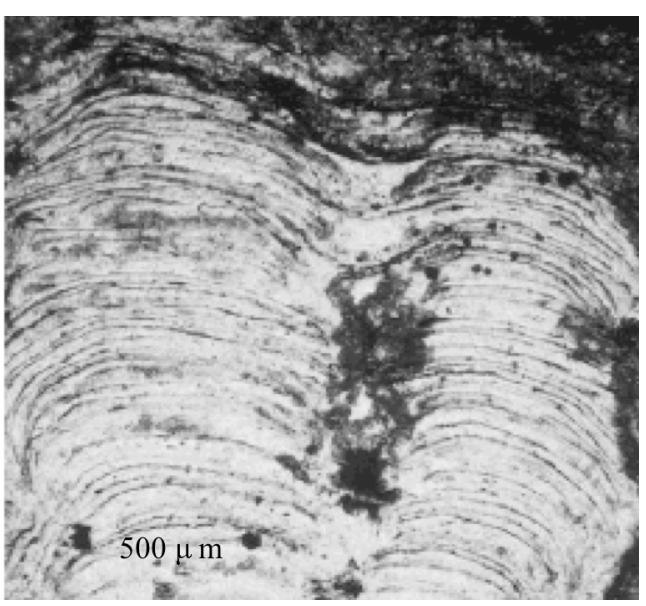

Fig. 3 - Fóssil de estromatólitos, em depósitos do Oeste Australiano, com aproximadamente 3.5 Ga (retirado de ALTERMANN \& KAZMIERCZAK, 2003).

Fig. 3 - Stromatolite fossils from the Western Australia deposits, with $3.5 \mathrm{Ga}$ (in ALtermanN \& KAZMIERCZAK, 2003).

Estudos micropaleontológicos realizados em rochas sedimentares da Série Fig Tree, na África do Sul, datadas de $3.1 \mathrm{Ga}$, revelaram a presença de microfósseis esféricos, interpretados como sendo provavelmente representantes de algas unicelulares. A presumível natureza fotossintética desses microorganismos primitivos parece estar de acordo com estudos isotópicos da matéria orgânica encontrada na Série de Fig Tree. Estes seres, semelhantes a algas, foram identificados na Série em conjunto com organismos semelhantes a bactérias (SCHOPF \& BARGHOORN, 1967; SCHOPF, 1993).

Foram ainda identificados microfósseis em rochas doutros locais: filamentos de cianobactérias com $2.75 \mathrm{Ga}$, na Formação de Tumbian no Oeste australiano; colónias de unicelulares em rochas sedimentares da Formação Towers, também no oeste australiano, datadas de $3.46 \mathrm{Ga}$ e filamentos semelhantes a bactérias em unidades do Supergrupo Swaziland, na África do Sul, datadas de 3.45 Ga. Para além dos depósitos de Tumbian, Towers e Swaziland, foram identificados estromatólitos noutros locais, em vinte e nove unidades geológicas do Arcaico (SCHOPF, 1993; MORRIS et al., 2003).

\subsection{Evidências indirectas de Vida}

O registo fóssil revela que a Vida surgiu na Terra há cerca de 3.5 Ga (WICANDER \& MONROE, 2000), idade aproximada dos fósseis mais antigos encontrados no Oeste australiano, na Formação
Apex Chert (SANKARAN, 2001). Outros autores apontam mesmo $3.8 \mathrm{Ga}$ ou valores compreendidos entre $3.8 \mathrm{Ga}$ e $3.5 \mathrm{Ga}$. As razões que os levam a considerar esta possibilidade são os resultados obtidos em análises isotópicas.

Os dados mais antigos de Vida resultam de evidências indirectas oriundas do Complexo Itsaq, no Oeste da Gronelândia. Estas rochas metassedimentares contêm pequenas esferas de carbono, provavelmente de origem biológica (NUTMAN et al., 2001; SUKUMARAN, 2001; BRASIER et al., 2002). Em rochas da Ilha Akilia, na Gronelândia, foram também encontradas evidências isotópicas (carbono orgânico) da presença de Vida há $3.8 \mathrm{Ga}$. Os agregados de carbono existentes nas rochas apresentam uma razão de 100 para 1 de ${ }^{12} \mathrm{C}$ (o isótopo de carbono mais comum, com 6 protões e 6 neutrões) para ${ }^{13} \mathrm{C}$ (isótopo de carbono mais raro, com 6 protões e 7 neutrões). O isótopo de carbono mais leve, ${ }^{12} \mathrm{C}$, é $3 \%$ mais abundante do que os cientistas esperavam encontrar caso a Vida não existisse. A origem biológica deste isótopo de carbono pode ter sido de microorganismos simples, contudo não é possível identificar qual o tipo (NuTMAN et al., 2001; ROLLINSON, 2001).

\subsection{Primeiras formas de Vida}

Actualmente a biosfera engloba milhões de espécies de animais, plantas e outros organismos, admitindo-se que todos estes evoluíram a partir de um ou alguns tipos primordiais que tiveram origem durante o Arcaico (SUKUMARAN, 2001).

Os dados recolhidos nas rochas fossilíferas mais antigas indicam-nos que os seres vivos primordiais foram cianobactérias fotossintéticas. Também diversos estudos apontam para a existência de organismos com capacidade autotrófica desde há 3.8 Ga (SHEN et al., 2001). Contudo, a fotossíntese é um processo metabólico extremamente complexo, o que leva a supor que possivelmente existiu um antecessor metabolicamente mais simples. Por este motivo, é frequente admitir-se que antes das cianobactérias podem ter existido seres vivos não fotossintéticos (SCHOPF, 1993; DoBRETSOV et al., 2006).

Apenas os conhecimentos actuais nos remetem para a existência de seres não fotossintéticos, uma vez que não existem fósseis daqueles primeiros organismos que se pensa poderem ter existido colonizando a superfície do planeta.

As características não oxidantes da atmosfera levam a supor que os primeiros seres fossem anaeróbios, ou seja, não necessitassem de oxigénio para as suas actividades vitais. Podem também ter sido heterotróficos, seres completamente 
dependentes do ambiente e das fontes de nutrientes que este lhes fornecia (SCHOPF, 1993; DOBRETSOV et al., 2006).

O registo fóssil mostra que eram células procarióticas, isto é, células extremamente simples em que a informação genética se encontra dispersa pelo citoplasma, uma vez que não existe invólucro nuclear a rodear o material genético (Raven \& Johnson, 2004). Aliás, muitos dos grupos de bactérias actualmente conhecidos provavelmente tiveram origem antes do fim do Arcaico (SCHOPF, 2001; MARGUlis \& DOLAN, 2002; FENCHEL, 2003).

As primeiras formas de Vida foram, portanto, anaeróbias, unicelulares, procariontes e heterotróficos. A sua principal fonte de nutrientes pode ter sido a adenosina trifosfato (ATP), molécula que constitui uma forma de energia utilizável pela célula. O ATP pode ser sintetizado a partir de gases simples e fosfato, os quais existiam sem dúvida no ambiente primitivo, estando portanto disponíveis para as primeiras formas de Vida. (SAITO et al., 2003; LENTON \& WATSON, 2004; RAVEN \& JOHNSON, 2004). Porém, esta situação não prevaleceu por muito tempo, uma vez que, com o surgimento de novas células estas competiam pelo ATP disponível no ambiente.

A razão apresentada é para muitos investigadores o indicador, nos primeiros organismos, de uma forma de metabolismo mais evoluído, como a fermentação, para a obtenção da energia necessária. Trata-se de um processo anaeróbio em que ocorre a degradação de moléculas como os glícidos (açucares), com libertação de dióxido de carbono, álcool e energia. É o que se passa actualmente, por exemplo, com as leveduras. Os organismos que realizavam fermentação estavam mais adaptados no meio e, como tal, reproduziam-se mais, transmitindo as suas características às gerações seguintes (SNOOKS, 2005).

Apesar da fermentação constituir um processo metabólico mais avançado, o evento biológico mais significativo do Arcaico foi o desenvolvimento, há cerca de $3.5 \mathrm{Ga}$, de um processo autotrófico, a fotossíntese. As células, apesar de anaeróbias, foram as responsáveis pelo enriquecimento da atmosfera em oxigénio. Com a capacidade de sintetizarem o seu próprio alimento, perderam a dependência que até então tinham em relação ao ambiente circundante. É precisamente de seres autotróficos, anaeróbios e procariontes que surgem as primeiras evidências fósseis, apesar de não serem consideradas as primeiras formas de Vida. Estes seres pertencem ao reino Monera, actualmente representado pelas bactérias e cianobactérias (COWEN, 2004).

\subsection{Paleoambientes suporte da Vida no Arcaico}

As bactérias, pertencentes ao actual grupo das Arqueobactérias (bactérias primitivas) vivem em ambientes isentos de oxigénio e parecem surgir em locais de elevada temperatura e elevada acidez, sob condições onde é detectada a presença de azoto, amónio e enxofre. Muitas destas bactérias actuais vivem em locais ricos em sulfato de hidrogénio (HS) e cianito de hidrogénio ( $\mathrm{HCN}$ ), junto a fontes hidrotermais oceânicas, do tipo "black smokers". Estas bactérias sugerem a ausência ou reduzida quantidade de oxigénio na atmosfera primitiva.

De acordo com o registo fóssil, as cianobactérias apareceram logo após as bactérias vulgares, há cerca de $3.5 \mathrm{Ga}$. Estes organismos, que ainda existem actualmente, formaram colónias e viveram em condições marinhas e terrestres, apesar de serem mais frequentes em zonas pouco profundas de plataforma. As marés são portadoras de partículas que as colónias de cianobactérias retêm construindo assim as estruturas designadas de estromatólitos (TUCKER, 1991).

Embora tenham sido abundantes nos oceanos primitivos, os estromatólitos são raros nos oceanos modernos, sendo encontrados em ambientes de condições extremas, tais como lagos hipersalinos e lagunas marinhas. Os estromatólitos modernos existem em grande quantidade em Shark Bay, na Austrália e nas Bahamas associados a lagunas hipersalinas (TAYLOR, 1993).

Os estromatólitos possuem camadas, produzidas pela actividade de cianobactérias. As camadas resultam da precipitação de carbonato de cálcio e agregação de partículas detríticas microscópicas nos interstícios e em torno dos indíviduos das colónias. À medida que as colónias de cianobactérias crescem, depositam-se novas camadas, dando origem à formação duma estrutura sedimentar estratificada. Nalguns casos os estromatólitos podem ter sofrido infiltração de soluções ricas em minerais o que permitiu a fossilização de bactérias (TUCKER, 1991; TAYLOR, 1993).

Os estromatólitos foram mais abundantes durante o Arcaico, desde há $2.8 \mathrm{Ga}$, tendo as cianobactérias contribuído significativamente para a oxigenação da atmosfera.

\section{Vida e Ambientes no Proterozóico}

\subsection{Tipos de organismos}

Os fósseis encontrados em rochas do Proterozóico são semelhantes aos do Arcaico, bactérias e cianobactérias. Porém, houve maior 
diversificação dos organismos ao longo do Proterozóico, tendo ocorrido evolução de vida a partir dos procariontes simples, já existentes desde o Arcaico. Até cerca de 2.1 Ga só são encontradas evidências de seres procariontes unicelulares e a partir desta data de seres mais complexos, eucariontes, e só posteriormente de seres multicelulares. $\mathrm{O}$ surgimento de reprodução sexuada conduziu também à diversidade, essencial no processo evolutivo.

\subsubsection{Jazidas fossilíferas importantes}

Nas rochas do Proterozóico os fósseis são mais frequentes comparativamente às do Éon Arcaico.

Os fósseis de células procarióticas foram inicialmente encontrados em chertes carbonatados em Ontário e Minnesota na formação conhecida por Gunflint Chert, de 2.0 Ga a 1.9 Ga. Esta formação apresenta grande variedade de organismos que parecem corresponder a seres procariontes, unicelulares semelhantes a bactérias e cianobactérias actuais (SCHOPF, 2001; KNOLL, 2004; WeSTALL, 2005).

Em 1965, doze anos após a sua descoberta, alguns organismos já tinham sido identificados como pertencentes aos géneros Gunflintia, Kakabekia, Eoastrion, Eosphaera, entre outros (BARGHOORN \& TYLER, 1965).

Os primeiros fósseis de seres eucariontes são do Proterozóico. São organismos com dimensão superior a 20 micrómetros, possuindo cromossomas, núcleo e organelos. Só posteriormente, em rochas mais recentes do que 1.4 Ga é que foram encontradas formas de Vida maiores, com diâmetro igual ou superior a 60 micrómetros (WAGGONER, 2001; KNOLL, 2003).

Os seres multicelulares, organismos constituídos por mais que uma célula, surgem pela primeira vez também em rochas do Proterozóico, distribuídas em vários locais do planeta. Os fósseis, de seres multicelulares, são mais abundantes em rochas com idades compreendidas entre os $1000 \mathrm{Ma}$ e $700 \mathrm{Ma}$. Pensa-se que nas rochas da Sibéria, China, Índia e Canadá, estejam preservadas algas (COWEN, 2004). Contudo, também foram encontradas evidências de algas multicelulares em rochas mais antigas, de 1.4 Ga, em Little Belt Mountains, em Montana, EUA. $\mathrm{Na}$ China foram encontrados fósseis que parecem ser algas, em rochas de idade $1.8 \mathrm{Ga}$, assim como na Negaunee Iron Formation de Michigan, de idade $2.1 \mathrm{Ga}$ (WiCANDER \& MONROE, 2000).

A Formação de Bitter Springs, exposta na Amadeus Basin, no centro australiano, contém os melhores e mais diversificados fósseis do Proterozóico. Estão presentes naquelas rochas cerca de trinta espécies de microfósseis, nos quais se incluem cianobactérias, algas verdes e, possivelmente, fungos, dinoflagelados e bactérias heterotróficas. Para além dos microfósseis, esta formação apresenta inúmeros estromatólitos. Os fósseis encontram-se bem preservados, sendo visível a estrutura interna de células, de grande dimensão.

As rochas onde foi encontrada a Fauna de Ediacara, é uma entre outras jazidas fossilíferas importantes, com características semelhantes, contendo seres que viveram entre $670 \mathrm{Ma}$ e $570 \mathrm{Ma}$ (MARGULIS \& DOLAN, 2002; NARBONNE \& GEHLING, 2003). Na fauna de Ediacara foram identificados, entre outros, os seguintes géneros: Pteridium (Cnidário), Tribrachidium (Cnidário?), Kimberella (molusco com concha), Charnia (Celenterado), Dickinsonia (Anelídio?), Mawsonites (Medusa). De salientar o organismo conhecido por Kimberella, encontrado na Rússia, e que apresenta características semelhantes a invertebrados marinhos actuais. Trata-se de um organismo com simetria bilateral, que possui pés musculares para locomoção e concha, o que constitui uma evidência dos primeiros organismos com esqueleto (KNOLL, 2004).

A Formação Doushantuo no Sul da China, datada de $600 \mathrm{Ma}$ a $570 \mathrm{Ma}$, contém extraordinários exemplares de fósseis de animais e respectivos embriões, acritarcas e algas multicelulares, algumas das quais macroscópicas (Fig. 4).
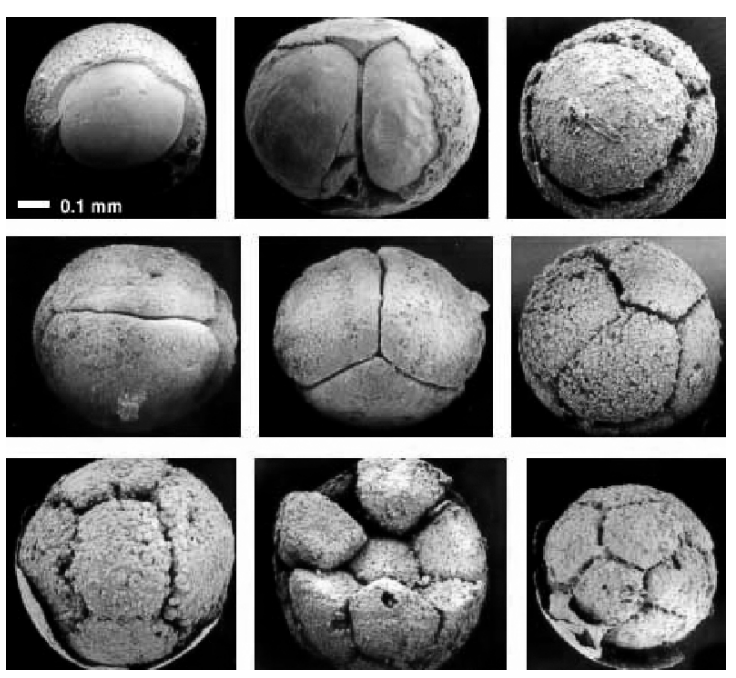

Fig. 4 - Fosseis de embriões animais encontrados na Formação Doushantuo (retirado de XIAO, 2004).

Fig. 4 - Embryos from the Doushantuo Formation (in XIAO, 2004). 
A Formação é famosa por conter esponjas e seres com simetria bilateral, assim como estádios de divisão celular perfeitamente preservados (XIAO, 2004). Esta fauna tem particular interesse pois, assim como a Fauna Tomotiana do Câmbrico inicial, fazem a transição entre a Fauna de Ediacara e a grande diversificação de Vida multicelular no Câmbrico.

Os acritarcas raramente são encontrados em rochas anteriores a $850 \mathrm{Ma}$ e $900 \mathrm{Ma}$, tendo por volta de $600 \mathrm{Ma}$, altura de uma grande glaciação do Proterozóico, sofrido extinção em massa (COWEN, 2004). A denominação acritarcas refere-se a um grupo de microfósseis esféricos com parede celular orgânica. Devido à sua semelhança com fósseis mais recentes de dinoflagelados, principalmente os quistos, estes acritarcas foram considerados a forma mais antiga daqueles organismos. Contudo, vários grupos de algas formam quistos com aspecto semelhante. Como não é possível efectuar estudos genéticos, pensa-se que sejam um taxon relacionado com algas eucarióticas, que constituíram o microplâncton marinho. Os acritarcas representam o limite superior da transição procariota-eucariota, que pode ter acontecido há $1400 \mathrm{Ma}$.

\subsubsection{Fósseis do Proterozóico em Portugal}

No território português as evidências paleontológicas anteriores ao Câmbrico são muito reduzidas. Pertencentes ao Proterozóico terminal, são encontradas na Serra do Marão rochas metamórficas de natureza xisto-grauváquica, onde foram identificados alguns exemplares de Lingulella major. Trata-se de uma espécie de braquiópode do género Lingulella que se destaca pela dimensão, podendo atingir $5 \mathrm{~cm}$ a $5,5 \mathrm{~cm}$ de comprimento e $1,9 \mathrm{~cm}$ a $2,1 \mathrm{~cm}$ de largura. Não apresenta grande valor estratigráfico, sendo-lhe atribuída uma idade entre o Proterozóico Superior e o Câmbrico Inferior. Contudo, tem sido frequentemente apelidado de "o mais antigo fóssil conhecido no país” (TEIXEIRA, 1981; ANDRADE, 1985; PEREIRA, 1989).

Em rochas da Zona Centro Ibérica, mas fora do território português, na região de Cáceres, foram encontrados estratos com fósseis de acritarcas (OliveIRA et al., 1992).

\subsection{Evolução biológica}

O Proterozóico inclui mais de $42 \%$ do tempo geológico e nele é encontrada maior variedade de organismos fósseis. Contudo, estes são, em larga escala, os seres que já existiam no Arcaico. Por exemplo na formação de ferro de Gunfilnt, no Canadá, apesar de terem sido encontradas doze espécies de microorganismos, estas são relativas apenas a bactérias e a cianobactérias.

No entanto, o registo fóssil sugere que ocorreu alguma diversificação de seres vivos neste intervalo de tempo. Ao contrário do que se passava no Éon anterior, no Proterozóico, há $2.1 \mathrm{Ga}$, existiram células mais complexas, as células eucarióticas, com núcleo organizado e perfeitamente individualizado (WICANDER \& MONROE, 2000).

O surgimento de variedade pode ser explicado pelo aparecimento da reprodução sexuada e relacionada com as primeiras impressões de seres multicelulares, algas e animais. O tamanho, a composição e a forma geral desses fósseis indicam seres eucariontes multicelulares fotossintéticos, provavelmente algas planctónicas. As evidências relativas a esta associação paleontológica parecem ter surgido abruptamente no registo fóssil, pois até então aparentemente não eram conhecidos animais. Por esta razão, diversos cientistas consideram que antes destes animais existiram outros com características mais simples. Nesta fauna foram identificados animais de pelo menos três filos de invertebrados actuais: cnidários (organismos de corpo mole e esponjas), anelídeos (vermes segmentados) e artrópodes (insectos, aranhas, etc.). Alguns animais apresentavam o corpo mole protegido por esqueleto resistente, quitina, carbonato de cálcio e ainda fosfato de cálcio.

\subsection{Surgimento das células eucarióticas, multicelularidade, reprodução assexuada e sexuada}

\subsubsection{Eucariotas vs Procariotas}

As células eucarióticas apresentam uma organização mais complexa, comparativamente às células procarióticas. Possuem uma membrana a rodear a informação genética, constituindo o núcleo. A maioria dos seres constituídos por este tipo de células, seres eucariontes, são pluricelulares e reproduzem-se sexuadamente. Por outro lado, os fósseis revelam a existência de dois processos de divisão celular. A mitose, essencial para o crescimento, renovação celular e nalguns casos reprodução assexuada, e a meiose, processo essencial na reprodução sexuada (SOLOMON et al., 1996).

As evidências fósseis referentes ao surgimento das células eucarióticas estão relacionadas com o tamanho e complexidade relativa. Normalmente as células eucarióticas são esféricas, maiores, mais complexas do que as procarióticas e o seu 
aparecimento no registo fóssil é mais recente. Estas evidências levaram os cientistas a postularem hipóteses para a origem das células eucarióticas. A teoria actualmente mais aceite e defendida, entre outros, por Lynn Margulis, tem o nome de teoria endossimbiótica (SOLOMON et al., 1996; HART, 2002; RAVEN \& JOHNSON, 2004). De acordo com os autores desta teoria, uma célula procariótica captou outras de tamanho menor, estabelecendo com estas uma relação de simbiose, com elevada eficácia (MARGulis \& FESTER, 1991).

\subsubsection{Multicelularidade}

O passo evolutivo posterior pode ter sido o surgimento da multicelularidade. Num ambiente povoado por um elevado número de seres unicelulares, os processos de competição por alimento foram frequentes. Pensa-se que foi nesta fase que surgiu a predação. Nesta situação um aumento de tamanho constituía uma clara vantagem. De facto, o registo fóssil mostra que os seres unicelulares chegaram a atingir dimensão superior a 60 micrómetros (RAVEN \& JOHNSON, 2004). Contudo, uma célula não pode crescer indefinidamente (FARABEE, 2001). Com o aumento do volume, dá-se um aumento do metabolismo o que implica um maior número de trocas com o meio onde o indivíduo se insere. Quanto maior for a célula, menor é a superfície da membrana por unidade de volume de citoplasma capaz de realizar trocas com o meio externo. Face a esta situação o ser pode ter contornado esta dificuldade reduzindo o seu metabolismo, ou seja, diminuindo as trocas com o meio ou então adquirindo multicelularidade (RAVEN \& JOHNSON, 2004).

É o estudo de organismos actuais que nos fornece pistas acerca do modo como surgiu a multicelularidade. Pensa-se que resultou de divisões sucessivas de um ser unicelular, originando um indivíduo formado por várias células, as quais permaneceram juntas como uma colónia. As células em determinadas colónias devem ter adquirido especialização, similar à que se verifica em organismos coloniais como o Volvox - colónia esférica de algas verdes. Posteriormente, este conjunto de células originou tecidos, os quais formaram órgãos especializados em determinadas funções no organismo (KIRK, 1997). Com o aparecimento da multicelularidade o metabolismo tornou-se mais eficiente, o que aumentou a eficácia na utilização da energia; os indivíduos tornaram-se maiores, o que lhes conferiu maior independência em relação ao meio externo e facilitou a procura de alimento e a fuga de possíveis predadores (KIRK, 1997; RAVEN \& JOHNSON, 2004).

\subsubsection{Reprodução assexuada e sexuada}

O surgimento de variabilidade pode também ser explicado pelo aparecimento da reprodução sexuada. Ao contrário da reprodução assexuada em que os novos seres resultam de um único progenitor e são geneticamente iguais a ele, na reprodução sexuada há intervenção de dois gâmetas, feminino e masculino, que por fecundação dão origem ao ovo, que originará um novo ser. Deste modo, os descendentes serão portadores de $50 \%$ do ácido desoxirribonucleico (ADN) de cada um dos seus progenitores. Também a ocorrência de mutações (alterações do material genético) durante a reprodução, introduz variedade nas populações (conjunto de seres vivos da mesma espécie que ocupam um determinado local).

A origem da reprodução sexuada não está esclarecida. Contudo, sabe-se que permitiu aos seres vivos responderem a alterações do meio. Segundo Charles Darwin, autor da teoria da Evolução, por selecção natural sobrevivem os indivíduos mais aptos às novas condições ambientais, acabando por se reproduzirem mais e originar maior número de descendentes (COWEN, 2004).

\subsection{Que paleoambientes sugerem?}

O aumento do número de cianobactérias e de depósitos com óxidos de ferro do tipo Red Beds sugerem a ideia de que ocorreu um aumento significativo do nível do oxigénio nos ambientes de sedimentação e na atmosfera (BLEEKER, 2004). Os seres eucariontes, como os Acritarcas e outros Protozoários, podem ter sido resultado de uma selecção natural que actuou sobre as formas de Vida capazes de tolerar o aumento do teor de oxigénio atmosférico. Contudo, o facto de os Metazoários serem todos de corpo mole e sem esqueleto, sugere que os níveis de oxigénio permaneciam ainda inferiores aos que se verificam actualmente e que o ambiente aquático continuava ácido demais para que as células fossem capazes de extrair os elementos da água do mar e segregar esqueletos. Os fósseis encontrados são essencialmente de seres aquáticos, sugerindo que a quantidade de oxigénio atmosférico não era suficiente para a formação da camada de ozono, barreira natural que oferece protecção contra a radiação ultra-violeta, para a maioria dos seres.

Os primeiros esqueletos de quitina, de sílica e de carbonato de cálcio, que surgiram na fase mais terminal do Proterozóico, evidenciam a disponibilidade no meio não só de sílica $\left(\mathrm{SiO}_{2}\right)$ como também de carbonato de cálcio $\left(\mathrm{CaCO}_{3}\right)$. Sugerem ainda diminuição da acidez do meio, que 
permitiu às células extrair dele os elementos químicos para a construção dos respectivos esqueletos.

A proliferação dos seres fotossintéticos teve por efeitos a produção de oxigénio e a modificação da composição da atmosfera, a qual por adição de oxigénio se tornou mais oxidante. À semelhança do que se verificava no Arcaico, também no Proterozóico a meteorização das rochas e os compostos emitidos pelas fontes hidrotermais foram fontes importantes de elementos químicos para a Vida.

\section{Diversidade de Vida NA Era Paleozóica, Éon fanerozóico}

Quando se fala dos aspectos biológicos do Câmbrico é frequente a utilização da expressão "explosão de Vida do Câmbrico". De facto, o registo fóssil parece apontar nesse sentido. Todavia, convém não confundir a ideia implícita no termo explosão com a disponibilidade de registo. $\mathrm{O}$ facto de ser encontrada grande variedade de seres pode ser resultado de maior disponibilidade do registo fóssil, uma vez que o volume das rochas preservadas pertencentes ao Câmbrico, período do Éon Fanerozóico, é maior que nos éones anteriores.

A transição entre o Proterozóico e o início do Fanerozóico, no período Câmbrico da Era Paleozóico, é marcada pelo aparecimento de animais portadores de esqueleto, pela elevada diversificação das comunidades de invertebrados marinhos e pelo aparecimento de espécies pertencentes a praticamente todos os Filos actuais. Salientam-se as jazidas paleontológicas da Fauna Tomotiana e da Biota Burgess Shale (KAZLEV, 2002). É a partir da Era Paleozóico que o número de géneros e exemplares fósseis começa a ser mais abundante no território nacional. Nos xistos dos afloramentos de Elvas - Vila Boim encontram-se trilobites, braquiópodes, lamelibrânquios e pterópodes (TEIXEIRA, 1981; OLIVEIRA et al., 1992).

Foi durante a Era Paleozóica que surgiram os primeiros vertebrados, nomeadamente os peixes. Mais tarde, já no Devónico, surgiram os anfíbios a partir de ancestrais de peixes, sendo os primeiros animais encontrados em rochas continentais do meio terrestre. No entanto, quando os ecossistemas terrestres foram colonizados por animais já neles se tinham fixado as plantas, desde o Silúrico. Apesar de tão diferentes, plantas e animais viram-se confrontados com as condições adversas dos ambientes terrestres. Deste modo, a ocupação dos ecossistemas terrestres não aquáticos conduziu ao aparecimento de novas características biológicas, resultantes da adaptação ao meio. O final do Paleozóico é caracterizado por grandes extinções em massa. Nestes eventos foram extintos organismos quer marinhos quer terrestres. Fazem parte desta lista, invertebrados marinhos, entre os quais as trilobites, alguns anfíbios e répteis (FARABEE, 2001).

\section{Considerações Finais}

Actualmente admite-se que a formação da Terra e dos restantes corpos do Sistema Solar tenha ocorrido há cerca de $4.6 \mathrm{Ga}$, pela acreção de uma nuvem de gases e poeiras associada a fenómenos gravitacionais que conduziram à evolução dos sistemas geosfera, hidrosfera e atmosfera terrestres. A geosfera adquiriu nos primeiros tempos da história da Terra a estrutura interna actual, por diversos processos de diferenciação geoquímica e geológica. Por sua vez, a evolução destes processos produziu os sistemas atmosfera e hidrosfera. A existência de atmosfera e de hidrosfera teve um papel muito importante e activo quer pela interacção sobre a geosfera quer juntamente com esta sobre as condições na superfície do Planeta. A presença de água no estado líquido gerou um novo grupo de processos geológicos, os de meteorização das rochas. $\mathrm{O}$ registo geológico relativo aos primeiros $4.0 \mathrm{Ga}$ é escasso, o que implica que a composição da atmosfera, da hidrosfera e as características climáticas não estejam totalmente conhecidas.

O estudo de diversos tipos de materiais, desde as rochas e minerais constituintes, valorizado pelos dados de geoquímica isotópica é cada vez mais aprofundado e simultaneamente mais questionado. Actualmente, perante os indícios apresentados e sua interpretação, algumas questões começam a ser esclarecidas. A existência de atmosfera pouco tempo após a formação do Planeta e com características muito distintas do presente não oferece dúvida. A presença da água no estado líquido, a hidrosfera, desde há $4.3 \mathrm{Ga}-4.4 \mathrm{Ga}$, abriu uma janela para a origem da Vida. A sua acção química sobre as rochas continentais, com a contribuição da atmosfera, deu origem a novos minerais, entre os quais as argilas, ficando disponível em solução um leque alargado de elementos químicos. As argilas viriam a ter um contributo importante como suporte para a Vida, permitindo que ao longo da história da Terra fossem reunidas as condições favoráveis ao seu aparecimento e desenvolvimento.

O estado actual dos conhecimentos permite assumir que a Vida surgiu no Arcaico, há 3.5 Ga a $3.8 \mathrm{Ga}$. A sua presença contribuiu para a evolução 
dos ambientes na Terra, interferindo directamente na composição da hidrosfera e da atmosfera. Uma vez instalada no Planeta, a Vida passou a interagir com as esferas terrestres (hidrosfera, atmosfera e geosfera), ocupando praticamente todos os ambientes resultantes da evolução da geosfera. Nesta interacção entre geosfera, hidrosfera, atmosfera e biosfera foram criadas condições distintas nos vários paleoambientes que forçaram as formas de Vida a diversificar-se, a evoluir e a ocupar quer os nichos ecológicos existentes quer os novos que se formaram.

\section{AGRADECIMENTOS}

O trabalho foi desenvolvido no âmbito das linhas de investigação do Núcleo de Ciências da Terra (NCT/UM), do Centro de Ciências da Terra (CCT/UM) e do Centro de Geologia da Universidade do Porto (CGUP), as duas últimas inseridas no Programa de Financiamento Plurianual da FCT, inscrito no POCTI inserido no III Quadro Comunitário de Apoio, co-financiado pelo Governo Português e pela União Europeia (FEDER). Os autores agradecem aos referees as sugestões que muito que contribuíram para o melhoramento deste artigo.

\section{BIBLIOGR AFIA}

AlbARÈDE F. (2003). Geochemistry, An Introduction. Cambridge University Press, Cambridge.

ALtermanN W. \& KAZMIERCZAK J. (2003). Archean microfossils: a reappraisal of early life on Earth. Research in Microbiology, vol. 154, pp. 611 - 617.

AMELIN Y. (2005). Geochemistry: A Tale of Early Earth Told in Zircons. Science, vol. 310, pp. 1914 - 1915.

ANDRADE A. A. S. (1985). Evolução (Paleogeográfica) do Território (Continental) Português. Geonovas, 8/9, Lisboa, pp. $53-68$.

ANDREWS J. E,. BRIMBLECOMBE P., JiCKELlSAND T. D. \& LiSS P. S. (1996). An introduction to Environmental Chemistry. Blackwell Science, Oxford.

BADA J. L (2004). How life began on earth: a status report. Earth and Planetary Science Letters, vol. 226, pp. 1 - 15.

BARGHOORN, E. S., \& S. TYLER (1965). Microorganisms fromthe Gunflint Chert, Science, vol. 147, pp. 563 - 577.

BARley M. E., BeKKer A. \& Krapez B. (2005). Late Archean to Early Paleoproterozoic global tectonics, envinonmental change and the rise of atmospheric oxygen. Earth and Planetary Science Letters, vol. 238, pp. 156 - 171.

BLEEKER W. (2004). Towards a "natural" time scale for the Precambrian - A proposal. Lethaia, Oslo, vol. 37, pp. $219-222$.

BOWLER P. J. (2003). The History of an Idea. University of California Press, Cambridge.

Brasier M. D.; OWen R. G.; JePhCOAT A. P.; KlePPe A. K.; VAN KRANENDONK M. J.; LindSAY J. F.; STEELE A. \& GRASSINEAU N. (2002). Questioning the evidence for Earth's oldest fossils. Nature, 416, pp. 76 - 81.

BURDIGE J. (2006). Geochemistry of Marine Sediments. Princeton University, Princeton.

Burnham R., Dyer A., \& KANIPE J. (2003). Astronomia, $O$ Guia essencial. Arte Mágica, Lisboa.
CAIRns-Smith, A. G. (1985). The First Organisms. Sci. Am., 252 , pp. $90-100$.

CAIRns-Smith A. G. (1990). Seven Clues to the Origin of Life. Cambridge University Press, Cambridge.

COCKELL C. S. (2004). Impact-shocked rocks - insights into archean and extraterrestrial microbial habitats (and sites for prebiotic chemistry?). Advances in Space Research, vol. 33, pp. $1231-1235$.

CORLiss J. B. (1989). Submarine hot springs again. Orig. Life Evol. Biosph. 19 (3-5), pp. 534 - 535.

Corliss J. B., BARoss J. A. \& HOFFMAN S. E. (1981). An hypothesis concerning the relationship between submarine hot springs and the origin of life on earth. Oceanologica Acta 4, pp. 59 - 69

COWEn R. (2004). History of Life. Blackwell Publishing.

DALRYMPLE G. B. (2001). The age of the Earth in the twentieth century: a problem (mostly) solved, in C.L.E. Lewis \& S. J. Knell (eds.) The age of the Earth: from $4004 B C$ to $A D$ 2002. Geological Society, London, Special Publications, pp. $205-221$.

DEAMER D. (2000). Origins of membrane structure, in L. Margulis, C. Matthews \& A. Haselton (eds.) Environmental Evolution: Effects of the origin and evolution of life on planet Earth. The MIT Press, London, pp. $67-83$.

Dobretsov N. L.; Kolchanov N. A. \& Suslov V. V. (2006). On the early stages of the evolution of the geosphere and biosphere. Paleontological Journal, vol. 40, pp. 407 - 424.

ENGel M. H. \& MACKO S. A. (1993). Organic Geochemistry: Principles and Applications. Plenum Press, New York.

FARABEE M. J. (2001). Paleobiology: The early Paleozoic. http://www.emc.maricopa.edu/faculty/farabee/BIOBK/Bio BookTOC.html (acedido em 18.12.2004).

FAURE G. (1986) Principles of isotope geology. John Wiley \& Sons, New York.

FAURE G. (1998). Principles and Applications of Geochemistry. Prentice-Hall, New Jersey.

FAURE G. (2001). Origin of Igneous Rocks. Springer, Ohio.

FENCHEL T. (2003). Origin and Early Evolution of Life. Oxford University Press, Oxford.

FERREIRA S. (2007). A Evolução da Geosfera como Contributo $e$ Suporte para a Vida. Tese de mestrado, Universidade do Minho (inédita).

FRIMMEL H. E. (2005). Archean atmospheric evolution: evidence from the Witwatersrand gold fields, South Africa. Earth Science Reviews, vol.70, pp. 1 - 46.

Gradstein F. M, Ogg J. G., Smith A. G., Bleeker W. \& Lourens L. J. (2004). A new Geologic Time Scale, with special reference to Precambrian and Neogene. Episodes, 27, pp. $83-100$.

GREGORIO B. T. \& SHARP T. G. (2003). Determining the biogenicity of microfossils in the Apex Chert, western Australia, using transmission electron microscopy. Lunar and Planetary Science XXXIV Meeting, 1267 pdf.

HART S. (2002). Eukaryotic Origins: Revolution in the Classification of Life.

http://www.astrobio.net/news/article243.html (acedido em 10.07.2006).

Hazen R. M.; Boctor N.; BRAndes J.; CODY G. D.; HeMley R. J.; SHARMA A. \& YODER H. S. (2002). High pressure and the origin of life, Journal of Physics: Condensed Matter, 14, pp. 11489 - 11494. 
Holland H. D. \& Kasting J. F. (1992). The Environment of the Archean Earth, in J. W. Schopf \& C. Klein (eds.) The Proterozoic Biosphere: A multidisciplinary Study. Cambridge University Press, Cambridge, pp. 21 - 42

Holland H. D. (2003). The Geologic History of Seawater. Treatise on Geochemistry, vol. 6, Harvard University, Cambridge, pp. 583 - 625.

Islas S.; Velasco A. M.; BecerRa A.; Delaye L. \& LazCano A. (2003). Hyperthermophily and the origin and earliest evolution of life. International microbiology, vol.6, pp. $87-94$.

KAMBer B. S.; MoORBATH S. \& Whitehouse M. J. (2001). The oldest rocks on Earth: time constraints and geological controversies, in C. L. E. Lewis \& S. J. Knell (eds.) The age of the Earth: from $4004 B C$ to $A D$ 2002. Geological Society, London, Special Publications, pp. 177 - 203.

KaUfMAN A.J.; KNOLL A.H. \& NARBONNE G. M. (1997). Isotopes, ice ages, and terminal Proterozoic earth history. Proc. Natl. Acad. Sci. USA,1994, pp. 6600 - 6605.

KAZLEV M. A. (2002). The Tommotian. http://www.palaeos.com/Paleozoic/Cambrian/Tommotian. $\mathrm{htm}$ (acedido a 10.11.2006)

Kelley D. S.; Karson, J. A.; FrÜH-Green G. L.; Yoerger D. R.; Shank T. M.; Butterfield D. A.; HAYes J. M.; SCHRENK M. O.; Olson E. J.; PROSKUROWSKI G.; JAKUBA M.; BRADLEY A.; LARSON B.; LUDWIG K; GLICKSON D.; BUCKMAN K.; BRADLEY A. S.; Brazelton W. J.; Roe K.; Elend M. J.; Delacour A.; BERNASCONI S. M.; LILLEY M. D.; BAROSS J. A.; Summons R. E. \& SYlva S. P. (2005). A SerpentiniteHosted Ecosystem: The Lost City Hydrothermal Field. Science, vol. 307, pp. 1428 - 1434.

Kelvin W. T. (1871). On the Origin of Life. $\mathrm{http} / / /$ zapatopi.net/kelvin/papers/on the origin of life.ht $\mathrm{ml}$ (acedido a 10.11.2006)

Kharecha P.; Kasting J. \& Siefert J. (2005). A coupled atmosphere-ecosystem model of the early Archean Earth. Geobiology, vol. 3, pp. 53 - 76 .

KIRK D. L. (1997). Volvox: A Search for the Molecular and Genetic Origins of Multicellulary and Cellular Differentiation. Cambridge University Press, Cambridge.

KNOLL A. H. (2003). Vestiges of a beginning? Paleontological and geochemical constraints on early animal evolution. Annales de Paleontologie, vol. 89, pp. 205 - 221.

Knoll A. H. (2004). Life on a Young Planet: The First Three Billion Years of Evolution on Earth. Princeton University Press, Princeton.

KNOPP R. E.; KiRSCHVINK J. L.; HiLbURN I. A. \& NASH C. Z. (2004). The Paleoproterozoic snowball Earth: A climate disaster triggered by the evolution of oxygenic photosynthesis. Proceedings of the National Academy of Sciences, vol. 102, pp. 11131 - 11136.

LENTON T. M. \& WATSON A. J. (2004). Biotic enhancement of weathering, atmospheric oxygen and carbon dioxide in the Neoproterozoic. Geophysical research letters, vol. 31, pp. L05202 1 - L 052025.

Margulis L. \& Dolan M. F. (2002). Early Life: Evolution on the Precambrian Earth. Jones and Bartlett Publishers.

Margulis L. \& Fester R. (1991). Symbiosis As a Source of Evolutionary Innovation: Speciation and Morphogenesis. MIT Press.

MARTI J. \& ERNST G. G. J. (2005). Volcanoes and the Environment. Cambridge University Press, Cambridge.

MoJzsis S. J.; HARRISON T. M. \& PIDGeON R. T (2001). Oxygen-isotope evidence from ancient zircons for liquid water at the Earth's surface 4,300 Myr ago. Nature, 409, pp. $178-181$

Morris P. A., Wentworth S. J., Allen C. C. \& MCKay D. S. (2003). Possible microfossils (Warrawoona Group, Towers Formation, Australia, 3.3-3.5 Ga). http://www.lpi.usra.edu/meetings/marsmet98/pdf/7033.pdf (acedido em 12.01.2004).

Muller A. W. J. \& SChulze-Maruch D. (2006). Thermal Energy and the origin of life. Origins of Life and Evolution of Biospheres, vol. 36, pp. 177 - 189.

NARBonNe G. M. \& GeHLing J. G. (2003). Life after snowball: The oldest complex Ediacaran fossils. Geolog-y, vol. 31, pp. 27 - 30.

NisBet E. G. \& SLEEP N. H. (2001). The habitat and nature of early life. Nature, vol. 409, pp. 1083 - 1091.

NutMan A. P.; Friend C. R. L. \& BenNetT V. C. (2001). Review of the oldest (4400-3600 Ma) geological and mineralogical record: Glimpses of the beginning. Episodes, vol. 24, pp. 93 - 101

Онмото H. (2001). The evolution of $\mathrm{O}_{2}$ and $\mathrm{CO}_{2}$ in the atmosphere. General Meeting of the NASA Astrobiology Insititute, pp. $231-232$.

Oliveira J. T.; Pereira E.; Piçarra J. M.; Young T. \& Romano M. (1992). O Paleozóico Inferior de Portugal: Síntese da estratigrafia e da evolução paleogeográfica, in J. C., Gutierrez-Marco; J. Saavedra \& I. Rábano (eds.), Paleozóico Inferior de Ibero-América. Universidad de Extremadura, España, pp. 359 - 375.

OpARIN, A. I. (1929/1938). The Origin of Life. Translation of the 1929 Russian publication by S. Morgulis. Macmillan, New York.

ORGEL L. E. (2006). The Origin of Life on the Earth. http://proxy.arts.uci.edu/ nideffer/Hawking/early proto/or gel.html (acedido a 02.04.2006).

PANOV A. D. (2005). Scaling law of the biological evolution and the hypothesis of the self-consistent Galaxy origin of life. Advances in Space Research, vol. 36, pp. 220 - 225

Pereira E. (1989). Notícia explicativa Carta Geológica de Portugal à escala de 1/50000, folha 10-A, Celorico de Basto. Serviços Geológicos de Portugal, Lisboa.

RAVEN P. H. \& JohNSON G. B. (2004). Biology. McGraw-Hill, England.

ROLLINSON H. (2001). The origin of life http://www.glos.ac.uk/gdn/origins/life/index.htm (acedido em 08.12.2004).

RUSHDI A. I. \& SiMONEIT B. R. T. (2006). Abiotic condensation synthesis of glyceride lipids and wax esters under simulated hydrothermal conditions. Origins of Life and Evolution of Biospheres, vol. 36, pp. 93 - 108.

Russel M. J. \& HALl A. J. (1997). The emergence of life from iron monosulphide bubbles at a submarine hydrothermal redox and $\mathrm{pH}$ front. Journal of the Geological Society, London, vol. 154, pp. 377 - 402.

Saito M. A.; Sigman, D. M. \& Morel F. M. M. (2003). The bioinorganic chemistry of the ancient ocean: the coevolution of cyanobacterial metal requirements and biogeochemical cycles at the Archean/Proterozoic boundary? Inorganica Chimica Acta, vol. 356, pp 308 . 318.

SANKARAN A. V. (2001). Discovery of life in greater than 2.6 billion-year-old terrestrial samples. Current Science, vol. 80, pp. 489 - 491.

SCHOPF J. W. \& BARGHOORN E. S. (1967). Alga-Like Fossils from the Early Precambrian of South Africa. Science, vol. 156 , pp. $508-512$ 
Schopf J. W. \& Klein C. (1992). The Proterozoic Biosphere: A multidisciplinary Study. Cambridge University Press, Cambridge.

SCHOPF J. W. (1992). Major Events in the History of Life. Jones and Bartlett Publishers.

SCHOPF J. W. (1993). Microfossils of the Early Archean Apex Chert: New Evidence of the Antiquity of Life. Science, New Series, vol. 260, pp. 640 - 646.

SCHOPF J. W. (2001). Cradle of Life: The Discovery of Earth's Earliest Fossils. Princeton University Press, Princeton.

Schopf J. W., Kudryavtsev A. B., Agresti D. G., Wdowiak T. J. \& CZAJA A. D. (2002). Laser-Raman imagery of Earth's earliest fossils. Nature, vol. 416, pp. 73 - 76.

SHARMA R. S. \& PANDIT M. K. (2003). Evolution of early continental crust. Current Science, vol. 84, pp. 995 - 1001.

SHEN Y., BUICK R. \& CANFIELD D. E. (2001). Isotopic evidence for microbial sulphate reduction in the early Archaean era. Nature, vol. 410, pp. 77 - 81.

SKINER B. J. \& PORTER S. C. (2003). Dynamic Earth. An Introduction to Physical GeologyI. John Wiley \& Sons, New York.

SNOOKS G. D. (2005). The origin of life on earth: A new general dynamic theory. Advances in Space Research, vol. 36, pp. $226-234$.

Solomon E. P., Berg L. R., Martin D. W. \& Ville C. (1996). Biology. Saunders College Publishing.

Stanley S. M. (1999). Earth System History. W. H. F. and Company, New York.

SuKUMARAN P. V. (2001). Early Planetary Environments and the origin of life. Resonance, vol. 6, pp. 16 - 28.

TAYLOR E. L. (1993). The Biology and Evolution of Fossil Plants.

http://www.ucmp.berkeley.edu/bacteria/cyanofr.html (acedido em 12-08.2006).
TeIXeIRA C. (1981). Geologia de Portugal, Volume I Precâmbrico, Paleozóico. Fundação Calouste Gulbenkian.

TORReS J. A. V. (1994). Estratigrafia, Principios y Métodos. Editorial Rueda, Madrid.

TRIBUTSCH H.; FIECHTER S.; JOKISCH D.; ROJAS-CHAPANA J. \& ELLMER K. (2003). Photoelectrochemical power, chemical energy and catalytic activity for organic evolution on natural pyrite interfaces. Orig. Life Evol. Biosph. 33(2), pp. $129-162$.

TUCKER M. E. (1991). Sedimentary Petrology: an introduction to the origino $f$ sedimentary rocks. Blackwell Science Ltd., Oxford.

VAN KRANENDONK M. J. (2006). Volcanic degassing, hydrothermal circulation and the flourishing of early life on Earth: A review of the evidence from c. 3490-3240 Ma rocks of the Pilbara Supergroup, Pilbara Craton, Western Australia. Earth - Science Reviews, vol. 74, pp. 197 - 240.

WAGGONER B. (2001). Eukaryotes and Multicells: Origin. Encyclopedia of Life Sciences, Macmillan Publishers, Ltd, pp. 1 - 9.

WALDE P. (2006). Surfactant assemblies and their various possible roles for the origin(s) of life. Origins of Life and Evolution of Biospheres. vol. 36, pp. 109 - 150.

Westall F. (2005). Life on the Early Earth: A Sedimentary View. Science, vol. 308, pp. $366-367$.

WiCANDER R. \& MONROE J. (2000). Historical Geology, Evolution of Earth and Life Trought Time. Brooks/Cole, USA.

WOESE C. (1998). The universal ancestor. Proccedings of the National Academy of Sciences of the United States, USA, vol. 95 , pp. 6854 - 6859 .

XIAO S. (2004). The Doushantuo Project. http://www.geol.vt.edu/paleo/Xiao/ (acedido em 30.07.2006).

ZEILIK M. \& GREGORY S. A. (1998). Introdutory Astronomy \& Astrophisics. Saunders College Pulishing, USA. 